\title{
Organizational Effectiveness in both Private and Publish Sectors in Iraqi Kurdistan, the role of Organization Culture and Leadership will be investigated
}

\author{
Sardar Hassan \\ A \\ Salahaddin University, Erbil
}

Article History: Received: 11 January 2021; Accepted: 27 February 2021; Published online: 5 April 2021

\begin{abstract}
This study explores the organizational effectiveness in both private and public sector organizations in Iraqi Kurdistan and examines whether organizational culture types and leadership styles influence organizational effectiveness. For that reason, a deep literature review was developed on that past studies. By using Competing Values Model (CVM) data were collected and measured. In order to answer the research questions and test hypotheses independently a sample of 272 managers form distinct organizations in both sectors are chosen for this research and correlation coefficient test and regression analysis methods are used to test the relation. Moreover, organizational culture and leadership style were regressed on organizational effectiveness. Thus, the managers' perception data indicate organizational effectiveness can be predicted by both organizational culture types and leadership style. Therefore, this author can conclude there is a positive relation between variables. The finding also shows that both independent variables can impact organizational effectiveness in public sector, while only leadership style can predict the dependent variable in private sector. At the end, some recommendations were proposed and further research in these areas was strongly advised.
\end{abstract}

Keywords: organizational culture, leadership, effectiveness, performance, efficiency, balanced scored card, criteria, measurement models, competing values model,

\section{Introduction}

Managers as leaders can be found everywhere, in all positions, genders and ages, it could be anyone from employees to volunteers and it has no racial or religious bounds, no ethnic or cultural borders (Kouzes and Posner, 2010). According to Hughes, et al. (2012) Leadership is both science and art, it is rational and emotional. Kouzes and Posners, (2010) added Leadership is dialogue process not monologue. It frequently involves empowering, training; provide instruction and leading others and delegating organizational tasks to employees (Rockall and Gertsch, 2001). (Avolio and Bass, 2004, 2002; Behn, 2010; Blunt, 2010; Drucker, 1955; Gilley, et al., 2010; Huczynski and Buchanan, 2007; Hughes, et al., 2012; Isaksen and Tidd, 2006; Mullins, 2005; Napoli, et al., 2005; Perkins, 2009; Perry, 2010; Quinn and Cameron, 2011, 2006; Van Wart, 2010) all these scholars see leadership as an important factor in brining effectiveness into organizations. Because, it is leader who create and share the vision of future and bring change and implemented it effectively. Schein (2010) suggested that leadership and organizational culture are like two side of coin needed in organizations and cannot be explained and understood without another.

From another side, Aquinas (2007) stated that organizational culture works as a framework that direct members' behaviour to achieve organizational goals and guide them in daily decision making and set goals that it must be aligned with managerial functions. Professionals and academics who view culture as a variable understand that organizations produce different cultural traits, such as values, norms, rituals, ceremonies, and verbal expression, which can affect the behaviour of peoples inside an organization (Alvesson, 2000). Alvesson stated that many scholars have stressed the importance of strong organizational culture in contributing to the systematic balance and effectiveness of an organization. Gray (1998) argued a synonymous for strong culture is highly homogenous or strongly shared culture which is viewed to be associated with high performance culture also viewed to be lead to inflexibility and ineffectively respond to change. For that reason, success is viewed as a product of interaction between both cultural and environmental factors. A successful organization must have strong culture that can attract, hold, and reward employees for good performance, and goal accomplishment (Sun, 2008). Datuon (2014) also discovered that strong culture stops culture changes when it is required to change by sustaining employees throughout the difficult times and serve to deflect anxiety. Additionally, McShane argued studies have found only modestly positive relations exist between strong culture and organizational performance because there are many subcultures. It is the leadership of organization that must recognize a healthy organization has subcultures with their own values may produce dominant values in the future (2000). Isaksen and Tidd (2006) pointed out that climate is a scalable concept too which can be examined at different levels inside organizations such as at work unit or group, division or functions, or at the whole organizational level, and as such, it is influenced by organizational culture. Although, a healthy climate that encourages support and cooperation throughout the organization alone will not ensure improved organizational effectiveness, but it is through a positive climate that an organization can achieve 
highest operational performance (Mullins, 2005). Robbins and Judge (2011) made it clear that psychological climate is strongly related to employees' level of job satisfaction, engagement, commitment and motivation. A positive environment is related to higher customer satisfaction and financial performance as well as employee's good well (Robbins and Judge, 2013).

The topics of leadership and organizational culture have proved themselves to everyone as a fascinating subject that need to be studied and researched. There are too many academic researches trying to investigate organizational culture and leadership style in different cultures, disciplines, organizational settings. Nevertheless, they were hardly examined in both private and public sector organizations at the same time at different managerial levels and in Iraqi Kurdistan. Once their organizational culture and dominant leadership style were explored, the impact of both variables as independent variables will be tested on organizational effectiveness. Reimann (1975) stated there is very little agreement between different scholars in the literature with regard to the factors that can forecast high or low effectiveness in an organization. The qualities of effective organizations were one of the major problems faced by many writers. The competing values model of effectiveness helps researchers address the problems of criteria dissonance and it helps analysts think of criteria as competing rather than as compatible (Cameron,1986).

\section{Literature Review}

\section{Effectiveness \& Performance}

Due to the lack of recent research on organizational effectiveness researcher was troubled to find current knowledge on this topic. Adding to the problem, many scholars used the phrase such as organizational performance, effective organizational performance, and corporate performance which create more confusion to the topic. Thus, this researcher realized there are different terminologies that are used interchangeably by different academics to indicate change or shift in the research. Cameron and Whetten (1996) stated that sometimes some terms such as performance, success, ability, efficiency, improvement, productivity or accountability are substituted for effectiveness but when it comes to measurement, effectiveness is usually what is required. Richard, et al. (2009, p.722) distinguished between organizational performance and organizational effectiveness and defined them as below:

"Organizational performance covers three specific areas of organizational outcomes: (1) financial performance such as profits, return on assets, and return on investment (2) product market performance such as sales and market share and (3) shareholder return such as total shareholder return and value added economy".

"Organizational effectiveness is broader than organizational performance and captures organizational performance plus the plethora of internal performance outcomes normally associated with more efficient or effective operations and other external measures that relate to considerations that are broader than those simply associated with economic valuation (either by shareholders, managers, or customers), such as corporate social responsibility".

Similarly, Forbes and Lynn (2007, p. 8) a PhD candidate has argued that performance is the narrower of the two concepts; basically it focuses on the outputs and outcomes of a program or policy. Forbes has also added that unlike organizational performance, organizational effectiveness is a broader notion that is concerned with the dynamics among principals and agents within and between the organizations comprising the system. Henri (2004) sees that the evolution of both measurement models as two brothers grown up similarly but progress differently. As a result, the organizational effectiveness models have significantly influenced the performance measurement models. According to Henri (2004) organizational effectiveness models reflect a construct perspective while the organizational performance models reflect a process perspective. Construct perspective focuses on the definition of the concept in term of assessment and conceptualization with the objective of deciding on dimensions the concept holds. In contrast, performance measurement models embody a process perspective where the emphasis is on the internal process and how to put effectiveness and efficiency into quantifying measurements. The performance measurement models progressed from a cybernetic view, measurement was based on financial measures which considered a component of planning and control cycle. A holistic view base on multiple nonfinancial measures where performance measurement acts as an independent process integrated in a broader set of activities (Henri, 2004 , p. 8). Both organizational and public management academics believe that both system performance and organizational effectiveness are related and used synonymously (Sowa et al., 2004). Isaksen and Tidd (2006) also pointed out that most of the private and public sector organizations use explicit measures of performance when intended to improve the performance. They have added, 'what gets measured gets managed'. Managers and civil servants most of the time tends to concentrate on data which can be easily gathered and already exist, added, having no measure is better than having inappropriate or easy measures. Matthews (2010) stated, only few organizations use performance measures because most measures report past performance rather a balance of financial and nonfinancial measures. He also criticized the performance measure for being imperfect indicator of an uncertain future, and it is unable to perfectly discriminate between good and bad performance. Carton and Hofer (2006) stated there are currently no 'generally accepted' measures of overall organizational performance which can be implemented in different studies to gain understanding based on strategic management. 


\section{Effectiveness \& Efficiency}

Frederick Winslow Taylor thought efficiency is everything, and he proposed that through the scientific management managers can determine jobs and practices as the way to improve efficiency and productivity (Daft, 2008).

\section{Organizational performance $=$ effectiveness $\mathbf{x}$ efficiency}

To measure the performance of organizations is to evaluate the effectiveness or the efficiency of the firm. Just like (performance and effectiveness) both (effectiveness and efficiency) concepts may look synonymous, yet they are very different in meanings. Efficiency is the ratio of input to output in a process whereas effectiveness assesses how outputs interact with the economic and social environment (Rollinson, et al., 1998; Bartuseviciene and Sakalyte, 2013). Daft (2012) suggested efficiency refers to the amount of resources (material, money, employees) used to accomplish company's goals, while, effectiveness as the degree to which an organization achieves its goals. Cameron and Whetten (1996) pointed to the early application of Weber's bureaucratic model to the topic of effectiveness and stated for Weber efficiency was the best evaluator of organizational performance and the more specialized, formalized, and centralized the better. Although, most organizations evaluate their performance in terms of effectiveness by focusing on the achievement of their mission, goals and vision, there are other organization measures their performance in terms of efficiency with an emphasis on the optimal use of resources to achieve the desired output (Bartuseviciene and Sakalyte, 2013). In another word, a firm is viewed productive if it can achieve its goals by successfully transforming its inputs into a good quality output at lowest cost, thus it is hard to have one without other, and productivity needs both efficiency and effectiveness (Huczynski and Buchanan., 2007; Robbins and Judge 2011; Rollinson, et al., 1998). From managerial points of views: efficiency emphasis 'doing things right' and links to inputs and what managers do. In contrast, effectiveness focuses on 'doing the right things' and relates to outputs of a task and what managers actually accomplish (Mullins, 2005). Strong higher management and human recourse standards are expected in high performance firm because of high expectations, recruitment and selections of the right individuals to achieve constant benchmarking. Better communication, interaction, leadership, direction, adaptability and positive environment are required if managers want to improve organizational effectiveness (Bartuseviciene and Sakalyte, 2013). Rollinson, et al. (1998) suggested neither efficiency nor effectiveness is achievable if human abilities, the environment that employees work within, and all the circumstances that motivate people are not considered.

\section{ORGANIZATIONAL EFFECTIVENESS}

Since 1950s, the concept of effectiveness was subject to numerous studies and researches within the organizational theory literature (Henri, 2004). Love and Skitmore (1996) added in the 1960's and 1970's research in organizational effectiveness was very popular between organizational researchers. Cameron (1986) argued despite the confusion surrounding effectiveness, the construct of organizational effectiveness is central to the organizational science. Effectiveness is universally accepted as a major goal for modern management (Welsh, et al., 1988). Today, organizational effectiveness focuses more on the employees' development due to the necessity of the necessary skills and capability of employees. Therefore, due to the complexity only few different studies have tried to define effectiveness. Moreover, organizational effectiveness is clearly a construct of central importance, it has too many problems and one of the major issues is the illusion surrounding the definition (Quinn and Rohrbaugh, 1983). Organizational effectiveness is inherently paradoxical. To be effective, an organization must possess attribute that are simultaneously contradictory, even mutually exclusive (Cameron, 1986, p. 545). Seashore and Yuchtman (1967) "observed effectiveness as the ability of the organization to exploit the environment in acquisition of critical resources. Price (1968) defined effectiveness as the degree of goal achievement" (cited in Love and Skitmore, 1996). Also Organizational effectiveness has been viewed as achieving goals at the organizational level by (Quinn and Rohrbaugh, 1983; Cameron and Whetten 1996). Thibodeaus and Favilla (1995) defined organizational effectiveness as the context to which an organization fulfils the objectives (cited in Lee and Tseng, N, D). Miller (2004) narrowly defined organizational effectiveness as the amount of physical output for each unit of productive input. Rollinson (1998) argued that there are similarities in definitions of organizational effectiveness by Daft (1989), Schroedeer (1989), and Koontz and Weihrich (1990) which focus is on achieving objectives or goal. Huczynki and Buchanan (2007) described organizational effectiveness as a multidimensional concept defined differently by different stakeholders, and it includes a range of quantitative and qualitative measures. Cameron (1986) stated the only agreement on organizational effectiveness is there is a disagreement over what organizational effectiveness is and how it can be measured. It is obvious that the majority of the organizational effectiveness definitions have concentrated on goal and resource attainment.

Similar to definition there are difficulties in having one ultimate criterion to measure organizational effectiveness (Cameron, 1978). Over the past years numerous and different criteria have been implemented to assess organizational effectiveness. Tthere is no solid agreement amongst scholars (Cameron, 1978-1980-1986; Cameron and Whetton, 1996; Henri, 2004). Cameron (1986, p. 541) pointed out consensus regarding the best, or sufficient, set of indicators of effectiveness is impossible to obtain, criteria are based on the value and preference of individuals, and no specifiable construct boundaries exist. There is a tendency to look at productivity, net profit, achieving 
organization mission and goals to assess the organizational success, while others concentrated on employees' moral, citizenship, turnover absenteeism, and satisfaction of members and commitment to organization, yet, all these criterions were tested and explored as insufficient and unsatisfactory (Angle and Perry, 1981; Cameron, 1978-19801986; Cameron and Whetten 1996; Luthans et al, 1988; Porter et al., 1979; Quinn and Rohrbough, 1983; Reimann, 1975; Shore and Martin,1989). There are two general types of problems which are the major obstacles in empirically evaluating organizational effectiveness, this include: one is related to the selection of the type of criteria and second is related to the sources of the criteria indicating effectiveness (Cameron, 1978, p. 605). He suggested that the problems of criteria types generally focus on (1) the aspect of organization being considered e.g., goal accomplishment (2) the universality or specificity of criteria, (3) the normative or descriptive characteristic of criteria, and (4) the static or dynamic quality of criteria. Cameron (1980) stated many managers use the past data to evaluate organization success. The problem with after-the-fact judgement is the narrow perspectives that do not contribute to long term organisational survival. Campbell (1974) identified nineteen different variables used to measure effectiveness. The most commonly used measures include: (a) overall performance (measured by employee or supervisory ratings); (b) productivity (actual output data); (c) employee satisfaction (self-report questionnaires); (d) profit (accounting data); and (e) withdrawal (turnover or absenteeism data) (Welsh, et al., 1988, p. 149). Matthews (2010) stated that the key performance measurements are nonfinancial, and encourages appropriate action and specify what it needs to be done which can be predicted by the top management; he presented ten different measurement areas as: strategic direction, market, financial, customer experience, flexibility, productivity, quality, delivery, cost, employee satisfaction. Martz (2013) suggested that the purpose of an organizational performance evaluation impact the type of data needed, data source, and the degree of evaluation anxiety presented. Therefore, from the above argument it is obvious that the chosen criteria would depend on individuals' viewpoints, their positions inside organization and their knowledge on topic.

There are many ways of looking at organizational effectiveness such as: the systems resource approach, the internal process approach, the goal approach, the stakeholder approach, the competing values approach, and the integrative approach and each one constitutes a different way in which it can be evaluated (Rollinson, et al., 1998, p. 440). According to Cameron (1986) no approach covers all contingencies or applies to all settings, each model has its own emphasis and strength and none of them can be directly substituted for the other models in evaluations, although a combination of criteria was presented in some studies. The below table (1) presents some of the main approaches to organizational effectiveness.

Table (1): Approaches to Organizational Effectiveness

\begin{tabular}{|c|c|c|c|c|}
\hline Approach & $\begin{array}{l}\text { Definition } \\
\text { An } \\
\text { organization is } \\
\text { effective to the } \\
\text { extent that...... }\end{array}$ & $\begin{array}{l}\text { Condition For } \\
\text { Use } \\
\text { The approach is } \\
\text { most preferred } \\
\text { when............ }\end{array}$ & $\begin{array}{c}\text { Conceptualizatio } \\
\text { n of the Organization }\end{array}$ & Focus \\
\hline $\begin{array}{c}\text { Goal } \\
\text { Attainment }\end{array}$ & $\begin{array}{l}\quad \text { It } \\
\text { accomplishes its } \\
\text { stated goals. }\end{array}$ & $\begin{array}{l}\text { Goals are clear, } \\
\text { consensual, } \\
\text { bounded, measurable }\end{array}$ & $\begin{array}{l}\text { Organization as a } \\
\text { rational set of } \\
\text { arrangements oriented } \\
\text { toward achieving } \\
\text { goals. }\end{array}$ & $\begin{array}{l}\text { Accomplishment } \\
\text { of outcomes (ends) }\end{array}$ \\
\hline $\begin{array}{l}\text { System } \\
\text { Resource }\end{array}$ & $\begin{array}{l}\quad \text { It acquires } \\
\text { needed } \\
\text { resources. }\end{array}$ & $\begin{array}{l}\text { A clear connection } \\
\text { exists between inputs } \\
\text { and performance }\end{array}$ & $\begin{array}{l}\text { Organization as an } \\
\text { open system (input, } \\
\text { transformation, } \\
\text { output). }\end{array}$ & \begin{tabular}{lr}
\multicolumn{1}{c}{ Inputs, } \\
acquisition \\
resources \\
internal \\
(means)
\end{tabular} \\
\hline $\begin{array}{c}\text { Strategic } \\
\text { Constituen } \\
\text { cies }\end{array}$ & $\begin{array}{l}\text { All strategic } \\
\text { constituencies } \\
\text { are at least } \\
\text { minimally } \\
\text { satisfied }\end{array}$ & $\begin{array}{l}\text { Constituencies } \\
\text { have powerful } \\
\text { influence on the } \\
\text { organization, and it } \\
\text { has to respond to } \\
\text { demands }\end{array}$ & $\begin{array}{l}\text { Organization as } \\
\text { internal and external } \\
\text { constituencies that } \\
\text { negotiate a complex } \\
\text { set of constraints, } \\
\text { goals and referents. }\end{array}$ & $\begin{array}{l}\text { Response to the } \\
\text { expectations of } \\
\text { powerful interest } \\
\text { groups that gravitate } \\
\text { around the } \\
\text { organization }\end{array}$ \\
\hline $\begin{array}{l}\text { Competing } \\
\text { Values }\end{array}$ & $\begin{array}{l}\text { The emphasis } \\
\text { on criteria in the } \\
\text { four different } \\
\text { quadrants meets }\end{array}$ & $\begin{array}{l}\text { The organization is } \\
\text { unclear about its own } \\
\text { criteria, or change in } \\
\text { criteria over time is of } \\
\text { interest. }\end{array}$ & $\begin{array}{l}\text { Organization as a } \\
\text { set of competing } \\
\text { values which create } \\
\text { multiple conflicting } \\
\text { goals. }\end{array}$ & $\begin{array}{l}\text { Three } \\
\text { dimensions of } \\
\text { competing values: }\end{array}$ \\
\hline
\end{tabular}




\begin{tabular}{|c|c|c|c|c|}
\hline & $\begin{array}{l}\text { constituent } \\
\text { preferences }\end{array}$ & & & $\begin{array}{l}\text { 1.Internal vs } \\
\text { external focus } \\
\text { 2. Control vs } \\
\text { flexibility concern } \\
\text { 3.Ends vs means }\end{array}$ \\
\hline Process & $\begin{array}{l}\text { It has an } \\
\text { absence } \\
\text { internal strain } \\
\quad \text { with smooth } \\
\text { internal } \\
\text { functioning }\end{array}$ & \begin{tabular}{l}
\multicolumn{2}{c}{ A clear connection } \\
exists between \\
organizational \\
processes and \\
performance.
\end{tabular} & ------ & ------ \\
\hline \begin{tabular}{c}
\multicolumn{1}{c}{ High } \\
Performing \\
Systems
\end{tabular} & $\begin{array}{l}\text { It is judged } \\
\text { excellent relative } \\
\text { to other } \\
\text { organizations. }\end{array}$ & \begin{tabular}{lr}
\multicolumn{2}{c}{ Comparison } \\
among & similar \\
organizations & are \\
desired &
\end{tabular} & & \\
\hline Legitimacy & \begin{tabular}{ll} 
& \multicolumn{2}{r}{ It survives as } \\
a result & of \\
engaging & in \\
legitimacy & \\
activity. &
\end{tabular} & $\begin{array}{l}\text { The survival or } \\
\text { decline and demise } \\
\text { among organizations } \\
\text { is of interest }\end{array}$ & ------ & ------ \\
\hline $\begin{array}{l}\text { Fault } \\
\text { Driven }\end{array}$ & $\begin{array}{l}\text { It has been } \\
\text { excellent relative } \\
\text { to other similar } \\
\text { organizations }\end{array}$ & \begin{tabular}{lr}
\multicolumn{2}{c}{ Comparisons } \\
among & similar \\
organizations & are \\
desired &
\end{tabular} & & - \\
\hline $\begin{array}{l}\text { Ineffective } \\
\text { ness }\end{array}$ & $\begin{array}{l}\quad \text { There is an } \\
\text { absence of } \\
\text { characteristics of } \\
\text { ineffectiveness }\end{array}$ & \begin{tabular}{l}
\multicolumn{1}{c}{ Criteria } \\
effectiveness are \\
unclear, strategies for \\
organizational \\
improvement needed
\end{tabular} & $\begin{array}{l}\text { Organization as a } \\
\text { set of problems and } \\
\text { faults. }\end{array}$ & $\begin{array}{l}\text { Factors that } \\
\text { inhibit successful } \\
\text { organizational } \\
\text { performance }\end{array}$ \\
\hline
\end{tabular}

Source: (Cameron, 1984, p. 276 cited in Love \& Skitmore, 1996; Henri, 2004)

How well an organization can achieve its goals is one of the approaches which according to Cameron (1980) is the one that was used most widely by executives. It focuses on how close the output is to organizational goals. For many rationalist authors such as (Price, 1968; Campbell, 1977; Scott, 1977) this model defines the characteristic of organizational effectiveness (Cameron, 1978). According to Love and Skitmore (1996) the criteria for this model include profit and productivity maximization. Henri (2004) suggested that the focus is exclusively on the ends: accomplishing the goals, objectives, targets, etc. Reimann (1975) argued most companies can have several different goals at different levels at the same time and the accomplishment of one goal often may inhibit the realization of another. Holland (2014) pointed to some other prominent authors such as (Cameron, 1985; Holland, T.P., 1988; Alton L. Taylor, 1989) that criticized the model over its limitation with public and non-governmental organizations. Because they believe the mission or goals of these organizations are to serve a specific group or clients served. According to Cameron (1978) Due to the criticisms of other scholars over the goal approach a new model as an alternative was introduced by Yuchtman and Seashore (1967). It focuses on how an organization is inter-acting with its environment and defines organizational effectiveness as how capable these organizations are in exploiting the environment and able to acquire the scares and valuable resources which ultimately can give those competitive advantage (Cameron, 1980). Reimann (1975) argued that Yuchtman and Seashore try to deal with this issue by abandoning the goal model in favor of a system-resource approach. While, Henri (2004) stated this model, try not to neglect with the importance of the ends, but argued the means is necessary for accomplishing specific ends. This model views the organization as an open system with inter-related subsystems. It starts by firm acquires inputs, engages in transformation processes, and generates outputs, thus if any subsystem perform poorly it will affect the overall effectiveness of organization performance (Henri, 2004; Love and Skitmore, 1996). West, et al. (2006) added although, external information and analysis are important, they are not sufficient to accomplish the needed result, thus manager needs to analyze organizational internal environment thoroughly. One of the main limitation of this model is it focuses on the means necessary to achieve effective performance rather than organizational effectiveness itself (Love and Skitmore, 1996). 
Nadler and Tushman (1980) proposed an internal congruence approach (Cameron and Whetten, 1996). This model unlike others relies on internal organizational process and operations of the company as the defining characteristics of effectiveness (Cameron, 1978). Also the internal functioning has to be smooth, information must flow in both directions smoothly, and trust should be high between employees and organization. Moreover, Daft (2010) proposed that clear communication, strong organizational culture and a positive work climate are linked to factors contributing to the smooth internal functioning and deliver effectiveness. Sparrow and West (2002) argued in each organization there are different individuals, how an organization makes use of its employees to accomplish its goals will have direct effect on its productivity and for an organization to be judged effective, we must evaluate how hard employees try to define and achieve organizational goals. Bartram, et al. (2002) have added that this statement is especially true in small size company, as organizations increase in size, so job position become more specialized and each members has smaller impact on organizational effectiveness, and organization itself will have difficulty increasing its employees' performance in pursuit of accomplishing overall goals. Pfister (2009) argued that internal control process is extremely complex, consists of many activities across, up and down, and in and out of company. These criticism and limitation of this approach lead authors to focus less on measurement criteria and more on the concrete expressions of stakeholders' expectations (Cameron and Whetten, 1996). In Strategic Constituencies approach, effectiveness is defined as the extent to which all of the company's strategic constituencies are at least minimally satisfied. Any groups of people who have some stake in the company are strategic constituencies (Cameron, 1980). Moreover, this approach measures the factors both within and outside the organization. Angle and Perry (1981) stated both organizations and their members are seen in an exchange relationship, each group demand different resources from other, while providing something in return. According to Henri (2004) both strategic constituencies model and stakeholder approach have the same organizational logic. Daft (2008) suggested that in stakeholder approach managers need to put a balance between the needs and interests of different stakeholders in setting goals and trying for effectiveness. Thus, the satisfaction level of each group can be assessed as a sign of organization's performance and effectiveness. Liu and Holland (2014) suggested "not for profit organizations are complex and work in dynamic environments with several of constituents which each has a stake in the organization and is likely to evaluate the organization's effectiveness in terms of what they define as desirable outcomes of performance". Cameron (1980) pointed out, this model is most useful when external constituencies have a strong impact on organization's operations. He added a charismatic leader can ignore stakeholders' demands and still be effective. It is obvious that all the above approaches have weaknesses and limitations. These made them less fit for measuring organization effectiveness, particularly public and NGO such as schools, universities, large service organizations.

According to Cameron and Whetten (1996, p. 272) after "recognizing that organizations are simultaneously pulled in opposite directions by the expectations of multiple constituencies led Quinn and his associates (Faehrman and Quinn, 1985; Quinn and Cameron, 1982; Quinn and Rohrbaugh, 1981) to develop and introduce the Competing Values Model of organizational effectiveness". They have argued that the inherently paradoxical nature of organizational functioning was recognized by this model and the managers need not only make tradeoffs among every day demands on company's resources, but, they must balance competing expectations regarding the core identity of the firm as an institution. This approach originated from the earlier models and represents the natural, logical extension of earlier eras of thoughts, it brings both external and internal attributes together which was originated in contingency theory, and also it uses expectations as the criteria for assessing effectiveness. Therefore, Cameron and Whetten, (1996) viewed this model as a more complex form of its earlier models which it allows organizations to operate in different environmental domains where each domains carrying different expectations. The mean idea behind this model is that there is not a specific set of criteria that can project organizational effectiveness in the best way and for that reason it needs to put different preferences under one model 'competing model'. Quinn and Rohrbaugh (1983, p. 370) pointed out that these three sets of competing organizational values are recognized dilemmas in the organizational literature. It shows the three dimensions and the actual location of the effectiveness criteria in the multi-dimensional space. The first dimension which is horizontal was interpreted as a reflection between two different organizational focuses. (Toward the left) the focus is on internal which mean person-oriented organization and (toward the right) the emphasis is on external which means organization-oriented. The second dimension which is vertical was interpreted as a reflection toward different organizational preferences for structure and to see whether an organization is interested in stability and control (toward the bottom) and flexibility and change (toward the top). and the last dimension which is a depth y-axis was interpreted as a reflection toward different degree of closeness to desired organizational outcomes or a means-ends continuum, to see whether an organization is concerned for end (nearer and larger) or concern for means (farther away and smaller). Henri, (2004) suggested that these sets of values cover different aspects of newer approaches: (1) means-ends dimension refers to the goal and system approaches, (2) the internal-external focus dimension refers to the different stakeholders' needs or constituencies approaches, and (3) the control-flexibility dimension is an open debate in organizational literature. Each of these three Competing values dimensions have been viewed and discussed as problems and managers need to solve them to accomplish organizational effectiveness. Quinn and Rohrbaugh (1983) argued that these three continuums have been recognized individually and identified as integrated elements 
of a single conceptual framework. They have stated that the separation of the 17 effectiveness criteria in the three dimensional space graphically define four models.

Quadrant 1: Human Relations Model - internal focus + flexible structure

In this quadrant, the focus of management is on the development of employees, members are empowered to learn and develop themselves, and managers work for sub-goals of organizations such as increase cohesion, morale, and provide training opportunities. Criteria as cohesion and moral are seen (as mean) and human resource development (as an End).

Quadrant 2: Open System Model - flexible structure + external focus

In this quadrant, managers are concerned with growth and resource acquisition; sub-goals are flexibility, readiness, and positive assessment by the external environment. Building a good relationship with external environment to grow and acquire resources are the main values of organization which is quite close to the System Resource Approach. This approach would stress criteria as flexibility, innovation and readiness (as means) and growth, resource acquisition, and external support (as ends).

Quadrant 3: Internal Process Model - internal focus + structural control

In this quadrant, the emphasis is on stability of organization and maintaining order because these types of organizations are well established in environment and they demand to carry on with this position. The sub-goals in this model are having mechanisms to communicate, make decision and managing information efficiently. The main criterion would stress the role of information management and communication (as means) and stability and control (as ends).

Quadrant 4: Rational Goal Model - Structural control + external focus

The management values reflect in this model is goals accomplishment including productivity, efficiency, and profit. The emphasis is on accomplishing output goals in controlled manners and sub-goals are internal planning and goal setting which are management functions. This quadrant is similar to the Goal Model and its main criterion of organizational effectiveness would stress planning and goal setting (as means) and productivity and efficiency (as ends) (Quinn and Rohrbaugh, 1983).

Cameron (1986, p. 550) suggested that diagonal quadrants are paradoxical to one another. In addition, Henri (2004) have looked at the relationship between different approaches, the complementary stance is the most suited to organizational effectiveness because each model presents us with a unique understanding of how organizational effectiveness constructed and as such researcher cannot totally take one for guarantee as a best model or completely ignore it. Yu and $\mathrm{Wu}$ (2009) found the CVF as one of the most influential and most widely used framework because both CVF and OCAI have better validity and reliability and very suitable for practical operations. Smerek (2010) argued the good thing about this model is it gives researchers a chance to compare across organizations and generalize about culture with high sample sizes. In opposite, however, researchers lose the uniqueness and complexity of culture in each organization and also it takes an objective view of culture. Therefore, this author believes the competing values model is the preferable model and demands to adopt this approach as an assessment method for measuring organizational effectiveness in this study. This study intends to investigate the influence of organizational culture and leadership as independent variables on organization effectiveness as a dependent variable in both private and public sector organizations in Kurdistan.

In recent years, the question of effectiveness has become increasingly important and similar to private sector, public sector organizations are under huge pressure to have their own plan, develop their own strategy and make use of scientific management practices to demonstrate their impact on complex social problems (Sowa, et al., 2004). Currently efficiency and effectiveness is one of the major governmental issues and governments' abilities in providing social services are under huge criticism (Schein, 2010). Julnes (2000) supported this argument by adding these criticisms are not new, governments around the world have tried many different attempts to find a solution in bringing both efficiency and effectiveness into their organisations, such as, introducing new decision-making techniques that can bring productivity to public administration organizations. Brewer and Selden (2000) indicated that improving the performance of government agencies and bring efficiency to public organizations are the central concerns of public management, and they have explained that the reasons that there is little understanding about these matter is due to the difficulty of the concept to define and evaluate, stakeholders' disagreement about which elements of performance are most important, and some time the elements have strong political implications. Parhizgari and Gilbert (2004) suggested in the private sector, there are boards of director and chief executive officers which their focus is to maximize shareholders' values. As a result, the internal structures and processes are designed to satisfy their customers. In contrast, public sector organizations are managed and run by someone who was elected by different stakeholders into office and these constituencies may not be consumer, for example, but they could be environmental protectionists, tax collectors, or immigration services. They have argued public organizations are more politically driven, while private sector organizations are more financially driven. The criteria to measure the effectiveness of private sector organizations are linked with the financial bottom line and long-term customer 
satisfaction and keeping customer, unlike public sector organizations. Quantitatively, these organizational effectiveness differences could have been different between both sectors.

Christensen, et al. (2007) stated that there is an opposing view to this traditional differences and believe that there are many scholars reject the idea that both organizations are different and dismissed them as stereotypes. These academics have found variables such as size, tasks and technology that can impact organizations more than their private or public status does. The public and private sectors have melted in certain areas, and too many organizations operate in the grey area - for example, an organization may well be public in some respects but private in others (Christensen, et al., 2007). Because public sectors organizations have no sort of funding except relying heavily on public fund, they under huge pressure to be accountable for their performance and achieving their goals which should reflect the organizational mission too. In their recent research on how Chinese and American perceive organizational effectiveness in non-profit organizations Liu and Holland (2014) have found that the executives and managers have described organizational effectiveness by how well they accomplish their goals and missions, satisfying multiple constituencies, maximise revenue and create positive reputation which echoed a similar emphasis in the literature. Talbot (2008, p. 10) stated that the "competing values framework emerged in the early 1980 from studies of public sector organizational effectiveness conducted at the institute for Government and Policy studies, at the state University New York at Albany. At first the model was developed to measure organizational effectiveness in for profit organizations. It has gained prominence between non-profit scholars (Sowa, et al., 2004). In one of Cameron and Quinn and Colleagues publication Talbot (2008) also found that CVF model works like a 'balanced scorecard' by showing that effective performance has different meanings in each competing quadrant, but they have concluded that by market rankings - the best companies tend to do well in all four competing quadrants as it goes through its life cycle. Abbett, et al. (2010) indicated in their master degree research that in ten years of literature review, the CVF was used 44 times in journals across applications as diverse as hospitals, performance review, TQM/Six Sigma, construction, virtual work, livestock production, engineering, real estate, nursing homes, higher education, orchestras, and hospitality. Parhizgari and Gilbert (2004) have summarized their research by suggesting that organizational effectiveness measures can be identified for both the public and private sector organizations. In practice, competing values framework can be applied to both sectors and they have added public organizations are getting more customer focused. Lincoln (2010) suggested that in this dynamic global economy, the competing values framework provides concrete ways to measure where the organization is, where it should be and readjusting managers to the entire organizational culture.

Does organizational culture affect corporate performance? McShane pointed to Nucor's CEO Ken Iverson and so many other writers that think so $(2000$, p. 505). These supportive Scholars argued that culture serves three important functions. (1) Organizational culture works unconsciously, (2) Organizational culture works as glue that brings people together, (3) Organizational culture assists the sense-making process. Coleman (2013) stated that the components of successful organizational culture can be distinguished into six different factors: 1 . Vision, 2. Values, 3. Practices, 4. People, 5. Narrative, 6. Place, and all of these can have impact the members' values and behaviours, therefore, can promote the effectiveness of organization's performance and innovation (Belias and Koustelios, 2014). Sparrow and West (2002) suggested that it is necessary for an organization to develop a culture that can create the mental, emotional and attitudinal states that precede effective employee performance. Sparrow and West (2002) reassured that organizational supports and fairness, employees' job satisfaction will make employees to be more committed and feels like the citizen of the organization which can lead to effective organizational performance. Cameron and Quinn (2006) suggested that when leaders, executives and employees within a firm have clear understanding of their organizational culture, it brings social order, continuity, collective identity, increase commitment which lead to effective organizational performance. Christensen, et al. (2007) pointed out that the activities of formal organization have evolved around the informal norms and values which are important in the context of organizational culture. They have added that even government ministry and a municipal unite can have their own organizational culture. In addition, Francois (2000) found out employees in public organization are motivated by public service stimulus, because they are concerned with outcomes. Managerial academics believe that there is strong correlation between strong culture and financial performance of organization. According to Heskett' "organizational culture can count for 20-30\% of the differential in corporate performance when compared with 'culturally unremarkable' competitors" (Belias and Koustelios, 2014). Cartwright and Baron (2002) confessed that in the past psychologists were more interested in the effect of individuals on organizational performance but lately the direction of research has changed toward a more macro level and argued that we have to accept the fact that culture differentiates organizations, that it influences behaviour and so contributes to organizational effectiveness. However, there are some scholars suggesting that the reverse relationship is true, meaning that it is the high performance that leads to the development of a strong organizational culture "cultural homogeneity" with a common set of orientations, beliefs and values (Alvesson, 2002). According to Rollinson, et al. (1998) there is very little evidence to show there is a strong correlation between culture and performance. In addition, this draws attention to contingency thinking that suggest in different conditions different types of cultures are needed and even contributes to efficiency (Alvesson, 2002). In another word, culture works as a regulatory mechanism in complex organizational settings. Mullins (2005) believes an adoptive culture is needed that can react and respond to changes 
in this dynamic environment. Alvesson (2002) in this sort of cultures, members are encouraged to take risk, build trust, and be proactive, and motivate to exploit the new opportunities.

In addition, leadership appears to be an important determinant of organizational effectiveness, whether we are discussing an army, an orchestra, a hockey team, a street gang, a political party, or a multinational company (Huczynski and Buchanan, 2007, p. 695). In organizations it is the effective leader that try to bring efficiency and effectiveness to work operation and increase the quality of goods and services too; it is the effective leader that provide a sense of cohesiveness, direction, vision, alignment with environment, works on developing employees, and increase members' satisfaction. Ineffective leaders are barriers in creation of healthy environment that encourage innovation, creativity, and a resource for revitalizing the organizational culture (Van Wart, 2010). Mullins (2005) argued that this matter was long recognized by many famous writers and prominent academics. He suggests there should be a relation between both the performance and the attainment of some purposes and criteria for measuring how effective a manager is (2005). Quinn and Cameron have discovered the highest - performing leaders are those who are self - contradictory, behaviourally complex leaders in the sense that they can be simultaneously hard and soft, entrepreneurial and controlled that allow them to succeed in each of the four organizational culture quadrants of CVF (2006, 2011). In another word, effective managers and effective organizations are paradoxical. Brown suggested that organizational culture can be a powerful tool for improving performance and the key to effective leadership and organizational development (Mullins, 2005, p. 898). The performance of organization is linked to leadership's characteristics because they have an influence over their followers and company's performance (Avolio and Bass, 1990). According to Isaksen and Tidd (2006) past researches on leadership and performance indicate that leadership directly influence and around $15 \%$ of the differences found in performance of businesses, and contributes around an additional $35 \%$ through the choice of business strategy. Thus, directly and indirectly, leadership can influence the performance of organizations. They believe although, leaders can have huge contribution to the performance of their organizations, yet, not all styles of leadership can have a clear impact on creativity, innovation and transformation. When management main tool in achieving performance is budgets then budgets can limit growth and distort organizational performance (Napoli, et al., 2005).

\section{Summary Statements \& Hypotheses}

This author strongly believes that there is a lack of research in this field in general and in Iraqi Kurdistan in particular. This study intends to explore the level of organizational effectiveness in the eyes of managers themselves and investigate the impact of organizational culture and leadership on organizational effectiveness in both private and public sectors. The intention is to make public sector as effective as private sector or probably to explore which sector is more active in each dimensions. The nine dimensions will be empirically derived for each sector and then will be compared pair-wise and jointly-across the two sectors. Thus, based on the literature review and the intention of this study, this research tries to propose two questions and three general hypotheses which are as below:

1. What is the level of effectiveness in both private and public sector organizations?

2. Is there relationship between organizational culture and leadership style with organizational effectiveness in both sectors?

3. Does organizational culture affect organizational effectiveness in both sectors?

4. Does organizational leadership style affect organizational effectiveness?

Hypothesis (1): there is positive relationship between organizational culture and organizational effectiveness in both sectors.

Hypothesis (2): there is positive relationship between organizational culture and organizational effectiveness in private sector.

Hypothesis (3): there is positive relationship between organizational culture and organizational effectiveness in public sector.

Hypothesis (4): there is positive relationship between organizational leadership and organizational effectiveness in both private and public sectors.

Hypothesis (5): there is positive relationship between organizational leadership and organizational effectiveness in private sector.

Hypothesis (6): there is positive relationship between organizational leadership and organizational effectiveness in public sector.

\section{Research Method}

The popular instrument that is used for identifying different features of organizational culture which can impact organizational performance is the competing values framework which originally based on competing values model (Cameron and Quinn, 2011). They believe organizational effectiveness is not objective but subjective and the outcomes preference is based on personal values. In this model, for an organization to be considered effective, it should focus on both short term and long term goals, be flexible and rigid, centralized and decentralized, goal and 
resource control oriented, and the needs of members and customers wants should be taken into account (Cameron and Whetten, 1996). Lincoln (2010) stated that the competing values framework is a perfect instrument to help managers analyze individuals and organizational culture. The Organizational Culture Assessment Instrument (OCAI) which is originally based on Competing Values Framework (CVF) was used in the past studies by this author to discover the current organizational cultures in both private and public sectors organizations. Therefore, because the competing values framework provides researcher with a chance to investigate the organizational culture and understand their level of effectiveness from different perspectives in both private and public sectors, he strongly believes it is necessary to adopt $\mathrm{CVF}$ as its main methodological framework. In addition, for measuring the organizational effectiveness in this study the dimensions were borrowed from the Competing Values Model (CVM) Cameron (1986) and modified by using Organizational Effectiveness Questionnaire (OEQ) (Steele, 1988, 106 cited in Nazarian, 2013). According to Nazarian (2013) the (OEQ) was created from organizational management development and change programs and literature on establishing superior-performance organizations which originally it has rooted from the (CVF). The dimensions are concerned with (1) employee job satisfaction, (2) employees' job development and customers' satisfaction, (3) employees' personal development, (4) supervisor and managers' satisfaction, (5) professional development and quality of department, (6) system openness and community interaction, (7) the ability to acquire resources, (8) organizational health and reward and punishment, (9) teamwork, group loyalty, trust and communication (Cameron and Quinn, 2011). Thus, by evaluating these different dimensions through this questionnaire it is hoped to give this researcher a measurement toll to assess the effectiveness of organizations in both private and public sectors.

\section{Sample, Data Collection \& Measurment}

In order to answer the research questions and test the hypotheses a quantitative research method is used to present the finding in a quantifiable style. The objective is to produce specific statistical facts and estimates data from a large representative sample of managers (Hiar, et al., 2002). A convenient sampling technique is used which is a non-probability sampling method and it is a subject to considerable sample errors if the sample was not chosen carefully (Baines and Chansarkar, 2002; Bryman and Bell, 2007). To make the sample population more representatives the sample was chosen between managers and professionals in different public and private sector organizations. Also the size, the location, the nature of business and customers were taken into considerations. Another effort to reduce the sample population errors the sample was drown on the bases of representivity, accessibility and functional equivalents. Thus, the target population is homogeneous "Kurd" and the majority of the participants are managers in low, medium, and senior positions geographically located in one province. Therefore, the research sample was not derived from a random selection process across private and public sector organizations in Kurdistan region but picked carefully. SPSS statistical package was used to measure data and present them in statistical and numerical styles. The functionality of the computer package was described by Landau and Everitt (2004) as programs for manipulating, analyzing, and presenting data. Thus, SPSS is used to calculate the standard deviations, means at aggregated level and the reliability of the items. Four different results were produced from the data analysis. The first part was concentrated on demographic data. The second part presents the Cronbach Alpha results to demonstrate the reliability of the questions. The third section produces some descriptive statistics data to measure the effectiveness of both sector organizations effectiveness. And the fourth and last part will present the results for correlation coefficient to test the hypotheses and regression analysis is to see the predictability of dependent variable by independent variables.

\section{Results}

\section{Frequency}

In order to bring consistency and reliability to the research sample this researcher tried to reach as many participants in different geographical area, different organizational levels and size and so 610 questionnaires were distributed. Out of the returned questionnaires only 272 or $45 \%$ of them were valid for this research. Out of the 272 participants 177 were male and 95 were female. Also 188 of them work for public sector organizations while only 84 of the respondents work for private sector.

\section{Reliability Test}

The reliability test will help researcher to find out whether the discovered data are reliable and the internal consistency is strong. It also explains whether there is strong correlation between items. To understand the properties of the measurement and explore the inter-consistency based on the average of inter-item correlation cronbach alpha was used in this research. The table (2-3) show the cronbach alpha for both private and public sectors separately as well as both sectors together with intraclass correlation coefficient results:

\section{TABLE (2): Reliability Statistics}




\begin{tabular}{|l|l|l|l|}
\hline & $\begin{array}{c}\text { Cronbach's } \\
\text { Alpha }\end{array}$ & Cronbach's Alpha Based on Standardized Items & N of Items \\
\hline Both sectors & .833 & .830 & 41 \\
Private & .804 & .797 & 41 \\
sector & .845 & .843 & 41 \\
Public sector & & & \\
\hline
\end{tabular}

TABLE (3): Intraclass Correlation Coefficient

\begin{tabular}{|c|c|c|c|c|c|c|c|}
\hline & \multirow{2}{*}{$\begin{array}{c}\text { Intraclass } \\
\text { Correlation }\end{array}$} & \multicolumn{3}{|c|}{$95 \%$ Confidence Interval } & \multicolumn{4}{|c|}{ F Test with True Value 0 } \\
\cline { 3 - 8 } & $\begin{array}{c}\text { Lound } \\
\text { Bound }\end{array}$ & $\begin{array}{c}\text { Upper } \\
\text { Bound }\end{array}$ & Value & df1 & df2 & Sig \\
\hline $\begin{array}{c}\text { Single } \\
\begin{array}{c}\text { Measures } \\
\text { Average } \\
\text { Measures }\end{array}\end{array}$ & $.106^{\mathrm{b}}$ & .088 & .127 & 5.976 & 271 & 1084 & .000 \\
& $.829 \mathrm{c}$ & .799 & .857 & 5.976 & 271 & 1084 & .000 \\
\hline
\end{tabular}

Two-way mixed effects model where people effects are random and measures effects are fixed.

a. Type A intraclass correlation coefficients using an absolute agreement definition.

b. The estimator is the same, whether the interaction effect is present or not.

c. This estimate is computed assuming the interaction effect is absent, because it is not estimable otherwise.

\section{Factor Analysis}

In order to reduce data to smaller numbers of variables those can describe most of the factors and also to explore the level of correlation within the set of searched items factor analysis is useful (IBM, 2010). Moreover, it helps the researcher in creating hypotheses to screen factors of subsequent analysis (SPSS, 2007). According to IBM (2010) the KMO measure of sampling adequacy examine the level of correlations between variables and Bartlett's Test of Sphercity try to discover the correlation matrix and whether it is an identity matrix that can indicate whether the factor model is appropriate or not. Thus the results show the KMOs for this study are .871 for both sector, .866 for public and .682 for private sector which are way above the average. This means the factor analyses are suitable for this study in all cases. And Sig number is 0.00 which is below the 0.05 is significant. Thus, the KMO is responsible for how many components need to be extracted for organizational effectiveness and the items with Eigenvalues of above 2 are what the researcher interested. An inspection of both eigenvalues and scree plot indicate that for organizational effectiveness there are 4 components are above the 2 which represent most of the cumulative percentages.

\section{Descriptive Analysis}

In producing summary statistics such as: means, standard deviation, minimum and maximum, descriptive analyses are useful. The means are what the researcher interested which they are based on all the data values made the level of effectiveness in both sectors. After aggregating and dividing the findings, for the first time this research produces some significant new and to some extend reliable results which they explain the level of effectiveness in private, public and combination of both sectors. The table (4) recaps the results:

Table (4): The level of Organizational Effectiveness in both Sectors Together \& Separately

\begin{tabular}{|c|c|c|c|c|}
\hline Dimensions & Questions & $\begin{array}{c}\text { Public } \\
\text { sector }\end{array}$ & $\begin{array}{c}\text { Private } \\
\text { sector }\end{array}$ & $\begin{array}{c}\text { Both } \\
\text { sectors }\end{array}$ \\
\hline Employee Job Satisfaction & $1-3$ & $60 \%$ & $59 \%$ & $60 \%$ \\
\hline $\begin{array}{c}\text { Employees' Job Development \& } \\
\text { Customers' Satisfaction }\end{array}$ & $14-18$ & $59 \%$ & $63 \%$ & $60 \%$ \\
\hline Employees' Personal Development & $25-27$ & $62 \%$ & $62 \%$ & $62 \%$ \\
\hline
\end{tabular}


investigated

\begin{tabular}{|c|c|c|c|c|}
\hline Supervisor \& Managers' Satisfaction & $4-7$ & $64 \%$ & $60 \%$ & $64 \%$ \\
\hline $\begin{array}{l}\text { Professional Development \& Quality of } \\
\text { Department }\end{array}$ & $19-24$ & $60 \%$ & $61 \%$ & $60 \%$ \\
\hline $\begin{array}{rlll}\text { System } & \text { Openness } & \& & \text { Community } \\
\text { Interaction } & & & \end{array}$ & $35-38$ & $59 \%$ & $58 \%$ & $58 \%$ \\
\hline The Ability to Acquire Resources & $39-41$ & $60 \%$ & $58 \%$ & $60 \%$ \\
\hline $\begin{array}{l}\text { Organizational Health \& Reward \& } \\
\text { Punishment }\end{array}$ & $8-13$ & $60 \%$ & $58 \%$ & $60 \%$ \\
\hline $\begin{array}{l}\text { Teamwork, Group Loyalty, Trust \& } \\
\text { Communication }\end{array}$ & $28-34$ & $59 \%$ & $58 \%$ & $59 \%$ \\
\hline
\end{tabular}

The above table presents some useful data on the level of effectiveness in both sectors. The findings exhibit there is no fundamental differences between both private and public sector organizations scores. According to Hair, et al. (2002) one of the problems with survey questionnaire is the participants may choose an answer which they think it may please the researcher or make them look nice since they know they are under observation. Additionally, there are some questions that may not apply to some organizations in either sector, yet, the participants tried to pick the option 3 which is feeling neutral. This researcher did not eliminate or exclude any items from the questionnaire even though he knew that some of them are not applying the employees in all situations. Also because all the data had high correlations the researcher believed it would be wise not to exclude any items. It is very important to notice that, from researcher point of view and experience, most of this dimension in this research and other research questionnaires that try to evaluate organizational effectiveness are almost irrelevant for this society. Thus, this study tries to create some reasons to be optimistic about the measurements but at the same time to be caution. Clearly there are factors such as size, industry and time that need to be considered while thinking about measuring organizational effectiveness. Moreover, there are other possibilities that some degree of common methods bias may steam from the survey process. Irrespective of these issues and recommendations that may not be so big, the need to continue to search the identification of organizational effectiveness measurement in both sectors now appears more forcefully.

\section{Hypotheses Testing}

In order to test the hypotheses and exam the relation between variables both correlation coefficient and regression analysis methods were used to strengthen the results. Multi-regression analysis is used to study the relation between organizational culture dimension and leadership style as independents variables and organizational effectiveness as dependent variable. According to Hair, et al. (2002) multi-regression method is extremely useful in examining the relation among several independent variables with a dependent variable. It predicts the value of dependent variable and demonstrates whether the dependent variable can be predicted and impacted by independent variables. In this study the focus was on R-Square values, B-Values, and P-Values. To strength the findings and double check the data; the stepwise technique was also used to demonstrate the included and excluded variables. Moreover, the table (5) shows the results for partial correlation coefficient statistics. The correlation coefficient tests variables explanatory strength on the dependent variable "organizational effectiveness". It also explains whether there is colinearity and multi-colinearity between two or more independent variables.

Table (5): Correlation Coefficient results

\begin{tabular}{|c|c|c|c|c|c|c|c|}
\hline & $\begin{array}{l}\quad \text { Cl } \\
\text { an } \\
\text { cultur } \\
\text { e }\end{array}$ & $\begin{array}{l}\text { Adho } \\
\text { cracy } \\
\text { culture }\end{array}$ & $\begin{array}{l}\text { Ma } \\
\text { rket } \\
\text { culture }\end{array}$ & $\begin{array}{l}\text { Hiera } \\
\text { rchy } \\
\text { culture }\end{array}$ & $\begin{array}{l}\quad \text { Transform } \\
\text { ational } \\
\text { leadership }\end{array}$ & $\begin{array}{l}\quad \text { Transac } \\
\text { tional } \\
\text { leadership }\end{array}$ & \\
\hline $\begin{array}{c}\begin{array}{c}\text { Organiza } \\
\text { tional } \\
\text { effectiveness }\end{array} \\
\text { Both } \\
\text { sectors }\end{array}$ & 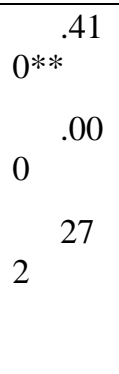 & $\begin{array}{l}.308^{*} \\
.000 \\
272\end{array}$ & $\begin{array}{ll} & .26 \\
& .26 \\
& .00 \\
0 & \\
& \\
& 272\end{array}$ & $\begin{array}{l}.298^{*} \\
* .000 \\
272\end{array}$ & $\begin{array}{l}.490 * * \\
.000 \\
272\end{array}$ & $\begin{array}{l}.095 \\
.117 \\
272\end{array}$ & $\begin{array}{l}\quad \text { Pea } \\
\text { rson } \\
\text { Correla } \\
\text { tion } \\
\quad \text { Sig. } \\
(2- \\
\text { tailed) } \\
\quad \mathrm{N}\end{array}$ \\
\hline
\end{tabular}




\begin{tabular}{|c|c|c|c|c|c|c|c|}
\hline $\begin{array}{c}\text { Organizat } \\
\text { ional } \\
\text { effectiveness } \\
\text { Public } \\
\text { sector }\end{array}$ & 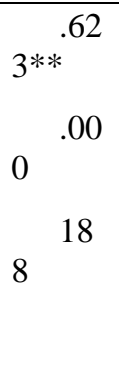 & $\begin{array}{c}.548 * \\
* .000 \\
188\end{array}$ & $\begin{array}{ll} & .38 \\
5 * * & \\
& .00 \\
0 & \\
& \\
& 188\end{array}$ & $\begin{array}{c}.493 * \\
* .000 \\
188\end{array}$ & $\begin{array}{l}.565 * * \\
.000 \\
188\end{array}$ & $\begin{array}{l}.270^{* *} \\
.000 \\
188\end{array}$ & $\begin{array}{l}\quad \text { Pea } \\
\text { rson } \\
\text { Correla } \\
\text { tion } \\
\quad \text { Sig. } \\
(2- \\
\text { tailed) } \\
\quad \mathrm{N}\end{array}$ \\
\hline $\begin{array}{c}\text { Organizat } \\
\text { ional } \\
\text { effectiveness } \\
\text { Private } \\
\text { sector }\end{array}$ & $\begin{array}{ll} & .05 \\
3 & \\
& 62 \\
9 & \\
& \\
& 84\end{array}$ & $\begin{array}{l}.023 \\
834 \\
84\end{array}$ & $\begin{array}{ll} & .00 \\
7 & \\
& \\
& .95 \\
0 & \\
& \\
& 84\end{array}$ & $\begin{array}{l}.162 \\
.141 \\
84\end{array}$ & $\begin{array}{l}.352 * * \\
.001 \\
84\end{array}$ & $\begin{array}{l}.029 \\
.793 \\
84\end{array}$ & $\begin{array}{l}\quad \text { Pea } \\
\text { rson } \\
\text { Correla } \\
\text { tion } \\
\quad \text { Sig. } \\
(2- \\
\text { tailed) } \\
\quad \mathrm{N}\end{array}$ \\
\hline
\end{tabular}

The above table shows the R-values as well as P-values of different independent variables and dependent variable. The first row demonstrates the independent variables and the second, third and fourth the results of the relationship with the dependent variable 'Organizational effectiveness'. The second row shows the results for both sectors together. Thus, there are muliti-colinearities between the variables and it explains that the organizational effectiveness can be strongly predicted by all the independent variables except transactional leadership style. Therefore, this researcher can include there is positive relationship between organizational culture and leadership styles with organizational effectiveness. The third row, demonstrate the results of managers' perception in the public sector organizations only. It explains that the organizational effectiveness in this sector can be predicted by all the variables and there is positive relationship between variables. The final row shows the results for managers in private sector organizations. Thus, the findings provide very different results compare to the above rows. It shows that there is no colinearity between the variables except the transformational leadership style. The only independent variable that can predict the organizational effectiveness in private sector organizations is the transformational leadership.

\section{Regression Analyses}

Table (6): Table summery

\begin{tabular}{|c|c|c|c|c|c|}
\hline $\begin{array}{ll}\text { Both } & \text { sectors } \\
\text { results } & \end{array}$ & Model & $\mathbf{R}$ & $\begin{array}{c}\mathbf{R} \\
\text { Square }\end{array}$ & $\begin{array}{l}\text { Adjusted } \\
\text { R Square }\end{array}$ & $\begin{array}{lr}\text { Std. } & \text { Error } \\
\text { of } & \text { the } \\
\text { Estimate } & \end{array}$ \\
\hline Clan culture & 1 & $.410^{\mathrm{a}}$ & . 168 & .165 & 91360770 \\
\hline $\begin{array}{l}\text { Hierarchy } \\
\text { culture }\end{array}$ & 2 & $.425^{\mathrm{b}}$ & .180 & .174 & .90868573 \\
\hline $\begin{array}{l}\text { Transformational } \\
\text { leadership style }\end{array}$ & 1 & $.490^{\mathrm{a}}$ & .240 & .238 & .87314329 \\
\hline \multicolumn{6}{|l|}{$\begin{array}{cc}\text { Public } & \text { sector } \\
\text { only } & \end{array}$} \\
\hline Clan culture & 1 & $.623^{\mathrm{a}}$ & .388 & .385 & .78449353 \\
\hline $\begin{array}{l}\text { Hierarchy } \\
\text { culture }\end{array}$ & 2 & $.647^{b}$ & .418 & .412 & .76693211 \\
\hline $\begin{array}{l}\text { Transformational } \\
\text { leadership style }\end{array}$ & 1 & $.565^{a}$ & 319 & .315 & .82744749 \\
\hline $\begin{array}{l}\text { Transactional } \\
\text { leadership style }\end{array}$ & 2 & $.626^{b}$ & .392 & .385 & .78394499 \\
\hline $\begin{array}{l}\text { Private sector } \\
\text { only }\end{array}$ & & & & & \\
\hline
\end{tabular}


investigated

\begin{tabular}{|c|c|c|c|c|c|c|}
\hline \begin{tabular}{|l} 
Transformational \\
leadership style
\end{tabular} & 1 & $.352^{\mathrm{a}}$ & .124 & .113 & \multicolumn{2}{|c|}{.94178201} \\
\hline \multicolumn{7}{|c|}{ Table (7): ANOVA } \\
\hline $\begin{array}{l}\text { BOTH SECTORS } \\
\text { RESULTS }\end{array}$ & Model & $\begin{array}{r}\text { Sum of } \\
\text { Squares }\end{array}$ & df & $\begin{array}{l}\text { Mean } \\
\text { Square }\end{array}$ & $\mathbf{F}$ & Sig. \\
\hline Clan culture & $\begin{array}{l}1 \\
\text { Regression } \\
\text { Residual } \\
\text { Total }\end{array}$ & $\begin{array}{l}45.637 \\
225.363 \\
271.000\end{array}$ & $\begin{array}{l}1 \\
270 \\
271\end{array}$ & $\begin{array}{l}45.637 \\
.835\end{array}$ & 54.676 & $.000^{\mathrm{a}}$ \\
\hline Hierarchy culture & $\begin{array}{c}2 \\
\text { Regression } \\
\text { Residual } \\
\text { Total }\end{array}$ & $\begin{array}{l}48.884 \\
222.116 \\
271.000\end{array}$ & $\begin{array}{l}2 \\
269 \\
271\end{array}$ & $\begin{array}{l}24.442 \\
.826\end{array}$ & 29.601 & $.000^{\mathrm{b}}$ \\
\hline $\begin{array}{l}\text { Transformational } \\
\text { leadership style }\end{array}$ & $\begin{array}{l}\text { 3Regression } \\
\text { Residual } \\
\text { Total }\end{array}$ & $\begin{array}{l}65.158 \\
205.842 \\
271.000\end{array}$ & $\begin{array}{l}1 \\
270 \\
271\end{array}$ & $\begin{array}{l}65.158 \\
.762\end{array}$ & 85.466 & $.000^{\mathrm{a}}$ \\
\hline \multicolumn{7}{|l|}{ Public sector only } \\
\hline Clan culture & $\begin{array}{c}1 \\
\text { Regression } \\
\text { Residual } \\
\text { Total }\end{array}$ & $\begin{array}{l}72.530 \\
114.470 \\
187.000\end{array}$ & $\begin{array}{l}1 \\
186 \\
187\end{array}$ & $\begin{array}{l}72.530 \\
.615\end{array}$ & 117.853 & $.000 \mathrm{a}$ \\
\hline Hierarchy culture & $\begin{array}{l}2 \\
\text { Regression } \\
\text { Residual } \\
\text { Total }\end{array}$ & $\begin{array}{l}78.186 \\
108.814 \\
187.000\end{array}$ & $\begin{array}{l}2 \\
185 \\
187\end{array}$ & $\begin{array}{l}39.093 \\
.588\end{array}$ & 66.464 & $.000 \mathrm{~b}$ \\
\hline $\begin{array}{l}\text { Transformational } \\
\text { leadership style }\end{array}$ & $\begin{array}{l}3 \\
\text { Regression } \\
\text { Residual } \\
\text { Total }\end{array}$ & $\begin{array}{l}59.652 \\
127.348 \\
187.000\end{array}$ & $\begin{array}{l}1 \\
186 \\
187\end{array}$ & $\begin{array}{l}59.652 \\
.685\end{array}$ & 87.125 & $.000^{\mathrm{a}}$ \\
\hline $\begin{array}{l}\text { Transactional } \\
\text { leadership style }\end{array}$ & $\begin{array}{l}4 \\
\text { Regression } \\
\text { Residual } \\
\text { Total }\end{array}$ & $\begin{array}{l}73.305 \\
113.695 \\
187.000\end{array}$ & $\begin{array}{l}2 \\
185 \\
187\end{array}$ & $\begin{array}{l}36.652 \\
.615\end{array}$ & 59.639 & $.000^{\mathrm{b}}$ \\
\hline \multicolumn{7}{|l|}{ Private sector only } \\
\hline $\begin{array}{l}\text { Transformational } \\
\text { leadership style }\end{array}$ & $\begin{array}{l}\text { Regression } \\
\text { Residual } \\
\text { Total }\end{array}$ & $\begin{array}{l}10.270 \\
72.730 \\
83.000\end{array}$ & $\begin{array}{l}1 \\
82 \\
83\end{array}$ & $\begin{array}{l}10.270 \\
.887\end{array}$ & 11.579 & $.001^{\mathrm{a}}$ \\
\hline \multicolumn{7}{|c|}{ Table (8): Coefficient } \\
\hline & $\begin{array}{r}\text { Unstan } \\
\text { zed Coeffi }\end{array}$ & $\begin{array}{r}\text { Uns } \\
\text { zed Co }\end{array}$ & $\begin{array}{l}\text { dardi } \\
\text { cients }\end{array}$ & $\begin{array}{l}\text { Standardi } \\
\text { zed } \\
\text { Coefficients }\end{array}$ & & \\
\hline
\end{tabular}




\begin{tabular}{|c|c|c|c|c|c|c|c|}
\hline $\begin{array}{l}\text { Both } \\
\text { sector } \\
\text { results }\end{array}$ & Model & B & Std. Error & Beta & & $\mathbf{t}$ & Sig. \\
\hline & $\begin{array}{c}1 \\
\text { (Constant) }\end{array}$ & $-4.195 \mathrm{E}-17$ & .055 & & & .000 & $00^{1.0}$ \\
\hline & culture $^{\text {clan }}$ & .410 & .055 & .410 & 4 & 7.39 & $\begin{array}{ll} & .00 \\
0 & \end{array}$ \\
\hline & $\begin{array}{c}2 \\
\text { (Constant) }\end{array}$ & $-6.157 \mathrm{E}-17$ & .055 & & & .000 & $00^{1.0}$ \\
\hline & culture $^{\text {clan }}$ & .348 & .064 & .348 & 5 & 5.47 & 0.00 \\
\hline & $\begin{array}{l}\text { hierarchy } \\
\text { culture }\end{array}$ & .126 & .064 & .126 & 3 & 1.98 & $8^{.04}$ \\
\hline & $\begin{array}{c}3 \\
\text { (Constant) }\end{array}$ & $8.186 \mathrm{E}-18$ & .053 & & & .000 & $00^{1.0}$ \\
\hline & $\begin{array}{l}\text { transformatio } \\
\text { nal } \\
\text { leadership }\end{array}$ & .490 & .053 & .490 & 5 & 9.24 & $\begin{array}{ll} & .00 \\
0 & \end{array}$ \\
\hline \multicolumn{8}{|l|}{$\begin{array}{l}\quad \text { Publi } \\
\text { c sector } \\
\text { only }\end{array}$} \\
\hline & $\begin{array}{c}1 \\
\text { (Constant) }\end{array}$ & $-3.522 \mathrm{E}-18$ & .057 & & & .000 & $00^{1.0}$ \\
\hline & culture $^{\text {clan }}$ & .623 & .057 & .623 & 56 & 10.8 & $\begin{array}{ll} & .00 \\
0 & \end{array}$ \\
\hline & $\begin{array}{c}2 \\
\text { (Constant) }\end{array}$ & $1.661 \mathrm{E}-17$ & .056 & & & .000 & $00^{1.0}$ \\
\hline & culture $^{\text {clan }}$ & .505 & .068 & .505 & 6 & 7.45 & 0.00 \\
\hline & $\begin{array}{l}\text { hierarchy } \\
\text { culture }\end{array}$ & .210 & .068 & .210 & 1 & 3.10 & $2^{.00}$ \\
\hline & $\begin{array}{c}3 \\
\text { (Constant) }\end{array}$ & $1.047 \mathrm{E}-16$ & .060 & & & .000 & $00^{1.0}$ \\
\hline & $\begin{array}{l}\text { transformatio } \\
\text { nal } \\
\text { leadership }\end{array}$ & .565 & .061 & .565 & 4 & 9.33 & $0^{.00}$ \\
\hline & $\begin{array}{c}4 \\
\text { (Constant) }\end{array}$ & $1.334 \mathrm{E}-16$ & .057 & & & .000 & $00^{1.0}$ \\
\hline & $\begin{array}{l}\text { transformatio } \\
\text { nal } \\
\text { leadership }\end{array}$ & .565 & .057 & .565 & 2 & 9.85 & $0^{.00}$ \\
\hline & $\begin{array}{l}\text { transactional } \\
\text { leadership }\end{array}$ & .270 & .057 & .270 & 3 & 4.71 & 0.00 \\
\hline
\end{tabular}




\begin{tabular}{|l|l|l|l|l|l|r|}
\hline $\begin{array}{l}\text { Priv } \\
\text { ate } \\
\text { sector } \\
\text { only }\end{array}$ \\
\hline & $\begin{array}{l}1 \\
\text { (Constant) }\end{array}$ & $4.729 \mathrm{E}-18$ & .103 & & .000 & 00 \\
\hline & $\begin{array}{l}1.0 \\
\text { transformatio } \\
\text { nal } \\
\text { leadership }\end{array}$ & .352 & .103 & .352 & 3.40 & 1 \\
\hline
\end{tabular}

a. Dependent Variable: organizational effectiveness

Hypothesis (1): there is positive relationship between organizational culture and organizational effectiveness in both sectors.

In order to test the relation between organizational culture and organizational effectiveness in both sectors multiregression method was used. The results indicated that both dominant organizational cultures 'Clan \& Hierarchy' $(\mathrm{B}=.348, \mathrm{P}<.000 \mathrm{a})$ and $(\mathrm{B}=.126, \mathrm{P}<.000 \mathrm{~b})$ have positive relation with organizational effectiveness and they are also the strong predictors. Whereas, market culture and adhocracy culture had negative relationship with organizational effectiveness, only in correlation coefficient test they show significant relation with organizational effectiveness. Moreover, R-square values of .168 and .180 for both cultures also suggest that both Clan culture and Hierarchy culture are good predictors of organizational effectiveness. The ANOVA F-values of 54.676 and 29.601 also explain the linearity of the relation between variables where P-values of .000 are below the conventional level of .01 and .05 levels of significance. Thus, the hypothesis 1 was supported. Therefore, this author can reject the null hypothesis and concludes that there is positive relationship between Clan and Hierarchy cultures of organizations in both sectors with organizational effectiveness and organizational effectiveness as a dependent variable can be predicted and influenced by these two independent variables.

Hypothesis (2): there is positive relationship between organizational culture and organizational effectiveness in private sector.

Both correlation coefficient and regression analysis tests suggest that the relation between organizational culture types as independent variables and organizational effectiveness as a dependent variable is negative. Thus, the hypothesis 2 was not supported and for that reason, the null hypothesis was accepted. Therefore, organizational effectiveness cannot be predicted by organizational culture types in private sector.

Hypothesis (3): there is positive relationship between organizational culture and organizational effectiveness in public sector.

The findings indicated that clan culture $(\mathrm{B}=.505, \mathrm{P}<.000)$ and Hierarchy culture $(\mathrm{B}=.210, \mathrm{P}<.002)$ with $\mathrm{R}$-square values of .385 and .412 are strong predictors of organizational effectiveness in public sector. Also the ANOVA Fvalues of 117.853 and 66.464 with P-values of .000a and $.000 \mathrm{~b}$ suggest there is linear relation between these variables. In addition, the correlation coefficient results show that there is positive relationship between the four organizational types and organizational effectiveness in public sector. Therefore, this author can conclude the hypothesis 3 was supported and the null hypothesis can be rejected. Unlike private sector organization both correlation coefficient and regression analysis findings demonstrated the strong relation between variables and suggest organizational effectiveness can be predicted and impacted by organizational culture types in public sector.

Hypothesis (4): there is positive relationship between organizational leadership and organizational effectiveness in both private and public sectors.

When the two sectors are tested together the findings show that Transformational leadership style $(B=.490$, $\mathrm{P}<.000)$ is the strong predictor of organizational effectiveness. The computed data demonstrate an R-square value of .240 is also an indication of the strong relationship between the two variables. Moreover, the ANOVA F-value of 85.466 with P-value of $.000 \mathrm{a}$ also suggests the linearity of the relationship. This result also was supported by correlation coefficient test which indicates there is positive relation with both transformational and Laissez-faire styles of leadership. Therefore, this author reject the null hypothesis and conclude there is positive relationship between both organizational leadership and organizational effectiveness and as dependent variable organization effectiveness can be predicted by organizational leadership style in both sectors.

Hypothesis (5): there is positive relationship between organizational leadership and organizational effectiveness in private sector.

The results for this hypothesis indicates that transformational leadership style $(\mathrm{B}=.352, \mathrm{P}<.001)$ is the strong predictor of organizational effectiveness in private sector. The R-square value of 11.579 with $\mathrm{P}$-value of 001 show 
the relationship exists between the two variables. Additionally, the ANOVA F-value of .124 also suggests the linearity of relationship between the independent variable and dependent variable. Thus, the hypothesis of 5 was supported. Therefore, this author reject the null hypothesis and conclude that both correlation coefficient and regression analysis tests indicate that organizational effectiveness can be predicted by transformational leadership style in private sector.

Hypothesis (6): there is positive relationship between organizational leadership and organizational effectiveness in public sector.

The findings for this hypothesis suggest transformational leadership style $(\mathrm{B}=.565, \mathrm{P}<.000 \mathrm{a})$ and transactional leadership $(\mathrm{B}=.270, \mathrm{P}<.000)$ have positive relation with organizational effectiveness in public sector organizations and organizational effectiveness can be predicted by leadership styles. The R-square values of .315 and .385 assume these leadership styles are the best predictors of organizational effectiveness in public sector. In another word, $31.5 \%$ to $38.5 \%$ organizational effectiveness can be predicted by both transformational and transactional leadership styles in public sector organizations. The ANOVA F-values of 87.125 and 59.639 with P-values of .000 also suggests the relationship is linear between the independent and dependent variables. Interestingly, these results are supported by correlation coefficient test. Thus, the hypothesis 6 is supported. Therefore, this researcher rejects the null hypothesis and conclude that there is positive relationship between these variables and organizational effectiveness can be predicted by organizational leadership styles in public sector organizations in Iraqi Kurdistan.

\section{Discussion}

For the first time in the literature history this study has explored some significant findings on organizational effectiveness areas in both public and private sector organizations in Iraqi Kurdistan. After investigating organizational effectiveness in both sectors and examining the hypotheses independently the results drown up some significant new findings. Organizational culture types and leadership styles were examined as independent variables (predictor) and organizational effectiveness as dependent variables. The descriptive data show the level of effectiveness in both private and public sectors is around 59\% to 64\% highest with little differences between both sectors. The results for both correlation coefficient and regression analysis also indicate the positive relation exists between variables. The findings also suggest that organizational effectiveness can be predicted and influenced by organizational culture and leadership style. Surji $(2014 ; 2015)$ also found that organizations in Iraqi Kurdistan in both private and public sectors are suffering from the lack of good visionary leaders, particularly in dealing with many factors such as increasing employee performance and satisfaction, and create an encouraging work environment and attaining rewards. Consequently, it can lead to inefficiency and organizational ineffectiveness. Surji recommended, better leadership practice and well develop employee recognition plan are needed to accomplish organizational mission with a gratifying culture. In addition, when each sector was examined independently, the tests produce some different results. The findings from managers' perception provide evidence that organizational culture and leadership style can influence and predict organizational effectiveness in public sector. In contrast, the relationship between organizational culture types and organizational effectiveness is negative in private sector organization. It also suggests only transformational leadership style is a strong predictor of organizational effectiveness in private sector; while transactional have negative relation with organizational effectiveness. This is probably because the private sector is new and small in Iraqi Kurdistan and their organizational culture is not well established to impact other variables.

Although, in the light of this in-depth study some important findings were explored and the results provide local and international academics and current literature some new and significant data which they can be used to update and expand the overall understanding on these complex areas, it was not out of weaknesses. This author admits that even though the sample population was based on managers and professionals working in both public and private sectors, there were some discrepancy and lack of awareness in both researcher and the participants' sides. At the pilot stage this researcher was troubled by some items as some of them can be viewed irrelevant or does not even exist in this society. The correlations between items were strong as the participants were answering all the questions even if it did not apply to them. Moreover, it worth to notice customer, employee and managers' job development and satisfaction either does not exist or viewed as part of administrable works that cannot be used in future assessments for promotional and reward reasons. Although acquiring resources dependent on the type of business and organizations but in general, employees and managers can and have very little chance to have a play or say something in resource distributions and acquisitions. Community work is only done when it is related to promotion or reward system and it goes with their states. The payment and reward system in here is old fashion and it is not scientific because there are not proper definitions for living standard, minimum wage, and poverty. Many academics still struggle in differentiating between teamwork and group work. Loyalty can mean different things as so trust and how a manager interprets these terminologies dependent on his/her perception and attitudes they are in. Yet despite all these concerns, this author decided to undertake this research but mention these concerns in his research. To sum up, this author can argue that trying and knowing is better than not doing or ignoring the concerns. He hopes that this study will lead to more research and a new model that can bring more understanding into the current knowledge.

\section{Research Implication}


This study provides an update and expands the current understanding on these complex areas of research. It produced some bases for local, international, private, public or a combination of all to understand the organizational effectiveness in Iraqi Kurdistan and how organizational culture and leadership can impact organizational effectiveness. This study also provides academic communities a chance to include this part of the world into their research and writing. It gives local and expatriates managers an opportunity on in which way they can make or change their organizational design and appraisal systems so it can fit best for this sort of societies and protect the interest of their stakeholders. Moreover, it helps government policy makers and legislators to investigate the new knowledge and explore how they can make public organizations more effective by changing the current system and issuing new law to take organizational appraisal more seriously and tie them to the reward and punishment system. This researcher urgently believes all organizations in both sectors needs to take these nine dimensions as their ways to improve and make their organizations more compatible with the rest of the world economy. This government is in the middle of serious crises such as: civil unrest, corruption, ISIS and central government dispute over the constitution and most importantly fiscal problems. Therefore, this author recommends to the current government to create a professional committee to investigate the suitability of the current evaluation system and whether the interest of different stakeholders is protected and served according to the constitutional principles.

\section{Conclusion}

The main aim of this research was to measure organizational effectiveness in Iraqi Kurdistan and investigate whether there are positive relations between organizational culture and leadership style with organizational effectiveness in both private and public sector organizations. To explore organizational effectiveness in both sectors Competing Values Model (CVM) was used which it was based on nine dimensions and have forty-one items. A cross-sectorial comparison was done to discover whether organizational effectiveness as a dependent variable can be predicted by organizational culture and leadership as independent variables and to understand whether the level of impact in both sectors is the same. To answer the questions and examine the hypotheses both correlation coefficient and multi-regression analysis methods were used in this study. The research findings show there is a positive relationship between the variables and organizational culture and leadership can influence organizational effectiveness in both sectors. Thus, they are the strong predictors of organizational effectiveness. Public sector organizations produce similar results to both sectors when combined and it indicates the positive relation exist between variables. In contrast, private sector organization culture shows negative relation, while transformational leadership style is a strong predictor of organizational effectiveness. Given the study effort to make public organizations in Iraqi Kurdistan at least as effective as the private sector organizations in the quality of services provided, the assessment of organizational effectiveness dimensions within and between each sector is now compared, measured, and improvement is recommended. Surprisingly the new findings reveal statistically there are not many significant differences across the two sectors effectiveness. Quality wise, however, there are both similarity and differences in Organizational effectiveness measures across sectors. Thus, this suggests that organizations in both sectors need to re-evaluate the performance appraisals, go through intensive training courses and hold them accountable to achieve excellent stakeholders' satisfaction and performance standards that they already lack. This will also increase employees and managers' morale, while contributing to organization's overall performance. The use of best practice in both sectors would make sense only if they find similar successful organizations in their industry. The new results should be reviewed by investors, international managers, government policy makers, professional academics and practitioners. For that reason, more research and attention should be giving to these complex areas.

\section{References}

1. Abbett, L., Coldham, A., \& Whisnant, R., 2010. Organizational culture and the success, of corporate sustainability initiatives: An empirical analysis using the Competing Values Framework. A project for Master of Science at the University of Michigan

2. Alvesson, M., 2002. Understanding Organizational Culture. London: SAGE Publications.

3. Angle, L. Harold., \& Perry, L. J., 1981-2007. An Empirical Assessment of Organizational Commitment and Organizational Effectiveness. Administrative Science Quarterly. Cornell University. Vol. 26, No. 1, pp. 1-14.

4. Aquinas, G. P., 2007. 1.1 Management Principles and Practice. 1.2 Organizational Behaviour. Bharathiar University, Coimbatore - 641046.

5. Avolio, B. J., \& Bass, B. M. (2004). Multifactor leadership questionnaire: Third edition manual and sampler set. Redwood City, CA: Mind Garden.

6. Avolio, J. B., \& Bass, M, B., ed. 2002. DEVELOPING POTENTIAL ACROSS A FULL RANGE OF LEADERSHIP" Cases on Transactional and Transformational Leadership. Center for Leadership Studies School of Management SUNY-Binghamton. London: Mahwah. New Jersey.

7. Baines, P., \& Chansarkar, B., 2002. Introducing Marketing Research. England: John Wiley \& Sons Ltd. 
8. Bartram, D., Robertson, I. I., Callinan, M., 2002. Introduction: A Framework for Examining Organizational Effectiveness : Robertson, T. I., Callinan, M., \& Bartram, D., ed. 2002. Organizational Effectiveness The Role of Psychology. UK: John Wiley \& Sons, Ltd.

9. Bartuševičienè, I., \& Sakalyte, E., 2013. ORGANIZATIONAL ASSESSMENT: EFFECTIVENESS VS. EFFICIENCY. Social Transformations in Contemporary Society, pp. 1-45.

10. Behn, D. R., 2010. Performance Leadership: Eleven Better Practices That Can Ratchet Up Performance: A Literature-Bassed Assessment In: Perry, L. J., ed. 2010.The Jossey-Bass Reader on Nonprofit and Public Leadership. San Francisco: Jossey-bass. Ch. 13.

11. Belias, D., \& Koustelios, A., 2014. Organizational Culture and Job Satisfaction: A Review. International Review of Management and Marketing. Vol. 4, No. 2, 2014, pp.132-149.

12. Blunt, R., 2010. How Leaders Are Grown: The Lessons of Example and Experience: A Literature-Bassed Assessment In: Perry, L. J., ed. 2010.The JosseyBass Reader on Nonprofit \& Public Leadership. SanFrancisco: Josseybass. Ch. 4.

13. Brewer, Gene A. and Selden, Sally Coleman., 2000. "Why Elephants Gallop: Assessing and Predicting Organizational Performance in Federal Agencies". Public Administration. Paper 1.

14. Bryman, A., \& Bell, E., 2007. Business Research Methods. Second Edition. United States; Oxford University Press.

15. Cameron, K., 1978. Measuring Organizational Effectiveness in Institutions of Higher Education. Cornel University. Vol, 23, pp. 604-628

16. Cameron, K., 1980. Critical Questions in Assessing Organizational Effectiveness. American Management Associations, pp, 66-80.

17. Cameron, S. K., \& Quinn, R., 2006. Diagnosing and Changing Organizational Culture, Based on The Competing Values Framework. Revised Edition. U.S.A. Jossey-Bass.

18. Cameron, s. K., \& Quinn, R., 2011. Diagnosing and Changing Organizational Culture, Based on The Competing Values Framework. Third Edition. U.S.A. Jossey-Bass.

19. Cameron, S. K., \& Wetten, A. D., 1996. ORGANIZATIONAL EFFECTIVENESS \& QUALITY: The Second Generation. Handbook of Theory \& Research. New York. Agathon Press. Vol. XI.

20. Cameron, S. K., 1986. EFFECTIVE AS PARADOX: CONSENSUS AND CONFLICT IN CONCEPTIONS OF ORGANIZATIONAL EFFECTIVENESS. Management Science. Vol. 32, No, 5.

21. Carton, B. R., Hofer, W. Charles., 2006. Measuring Organizational Performance, Metrics for Entrepreneurship and Strategic Management Research. UK: Edward Elgar.

22. Cartwright, S., \& Baron, H., 2002. Culture and Organizational Effectiveness: Robertson, T. I., Callinan, M., \& Bartram, D., ed. 2002. Organizational Effectiveness The Role of Psychology. UK: John Wiley \& Sons, Ltd. Ch. 8.

23. Cartwright, T., \& Baldwin, D., 2010. Seeing Your Way: Why Leaders Must Communicate Their Visions: A Literature-Bassed Assessment In: Perry, L. J., ed. 2010.The Jossey-Bass Reader on Nonprofit and Public Leadership. San Francisco: Jossey-bass. Ch. 21.

24. Christensen, M. C., \& Overdorf, M., 2005. Meeting the Challenge of Disruptive Change. Zurich: This article originally appeared in, Harvard Business Review.

25. Christensen, T., Per Lægreid, Paul, G. R., \& Rovik, K. A., 2007. Organization Theory and the Public Sector, Instrument, Culture and Myth. USA and Canada: Routledge.

26. Daft, L. R., 2008. Organisation Theory \& Design. 10th. Canada: South-Western, Cengage Learning.

27. Daft, L. R., 2010. Organisation Theory \& Design. 11ed. Canada: South-Western, Cengage Learning.

28. Datuon, Q. R., 2014. Competing Values Framework of Administrators among Private Colleges in the National Capital Region. The Carrington Rand Journal of Social Sciences, Vol. 1, No. 1, 024-034.

29. Forbes, M., 2007. Governance and Organizational Effectiveness: Toward a Theory of Government Performance. PhD Candidate, Ford School of Public Policy and Department of Sociology. University of Michigan

30. Francoisa, P., 2000. 'Public service motivation' as an argument for government provision. Journal of Public Economics. Elsevier, Netherlands, 78, pp 275-299

31. Gilley, A., Dixon, P., \& Gilley W. J., 2010. Characteristics of Leadership Effectiveness: Implementing Change and Driving Innovation in Organizations: A literature-Based Assessment In: Perry, L. J., ed. 2010.The Jossey-Bass Reader on Nonprofit and Public Leadership. San Francisco: Jossey-bass. Ch. 25.

32. Gray, J. R., 1998. Organizational Culture and Psychological Contract, A review of the literature. UK: Published by Cumpania Consulting.

33. Hair, F. J. JR., Bush, P. R., Ortinuau, J. D., 2002. Marketing Research Within a Changing Information Environment. London: The McGraw-Hill Companies.

34. Henri, F. J., 2004. PERFORMANCE MEASUREMENT AND ORGANIZATIONAL EFFECTIVENESS: BRIDGING THE GAP, ResearchGate.

35. Huczynski, A. A., \& Buchanan, A. D., 2007. Organizational Behaviour. Six Edition. England: FT Prentice Hall. 
36. Hughes, L. R., Ginnett, C. R., \& Curphy, J. G., 2012. Leadership, Enhancing the Lessons of Experience. Seven Edition. America: McGraw-Hill/Irwin.

37. IBM SPSS Statistics Base 19. 2010. Copyright SPSS Inc.

38. Isaksen, S., \& Tidd, J., 2006. Meeting the Innovation Challenge: Leadership for Transformation and Growth. England: Published by John Wiley \& Sons Ltd.

39. Kouzes, M. J., \& Posner, Z. B., 2010. The Five Practices of Exemplary Leadership: A Literature-Bassed Assessment In: Perry, L. J., ed. 2010.The Jossey-Bass Reader on Nonprofit and Public Leadership. San Francisco: Jossey-bass. Ch. 3.

40. Landau, S., \& Everitt, S. B., 2004. A Handbook of Statistical Analyses using SPSS. London: Chapman \& Hall/CRC Press LLC.

41. Lee, Z. T., \& Tseng, Y., N.D. A Study of the Relationship between Organizational Culture and Organizational Effectiveness of the Electronic Industries in Taiwan.

42. Lievens, F., Geit, V. P., \& Coetsier, P., 1997. Identification of Transformational Leadership Qualities: An Examination of Potential Biases. EUROPEAN JOURNAL OF WORK AND ORGANIZATIONAL PSYCHOLOGY, University of Ghent, Belgium 6 (4), pp. 415-430

43. Lincoln, S., 2010. From the Individual to the World: How the Competing Values Framework Can Help Organizations Improve Global Strategic Performance. Emerging Leadership Journeys, Vol. 3 Iss. 1, pp. 39. Handong Global University

44. Liu, C., \& Holland, P. T., 2014. Chinese and American Perceptions on Nonprofit Organizational Effectiveness. Cambridge Journal of China Studies.1Central South University, China, 2University of Georgia, USA

45. Love, P., E.D. and Skitmore, M. R. 1996. Approaches to Organisational Effectiveness and Their Application to Construction Organisations. In Thorpe, A., Eds. Proceedings 12th Annual Conference and Annual General Meeting, The Association of Researchers in Construction Management, Sheffield Hallam University.

46. Luthans, F., Welsh, D.H.B., \& Taylor, L., 1988, June. A descriptive model of managerial effectiveness. Group \& Organization Studies, 13(2), pp. 148-162.

47. Martz, W., 2013. Organizational Effectiveness; Evaluation Checklist

48. Matthews, J., 2010. Organizational Effectiveness. Baltimore, MD

49. McShane, L.S., 2000. Organizational Culture. Chapter Sixteen: pp. 497-521.

50. Miller, H., 2004. Quantifying and Fostering Organizational Effectiveness. Herman Miller Inc.

51. Mullins, J. L., 2005. Management and Organizational Behaviour. Seven Edition. England: FT, Prentice Hall.

52. Napoli, D., Witeley, M. A., \& Johansen, S. K., 2005. Organizational Jazz Extraordinary Performance through Extraordinary Leadership. First Edition. Malaysia: Vivar Printing Sdn Bhd.

53. Nazarian, A., 2013. The Mediating Influence of Leadership Style and Moderating Impact of National Culture and Organizational Size on the Culture-Effectiveness Relationship: The Case of Iran. Brunel University London: A Doctoral thesis.

54. Parhizgari, M. A., \& Gilbert, R. G., 2004. Measures of organizational effectiveness: private and public sector performance. The International Journal of Management Science. Omega, pp. 221-229.

55. Perkins, W. A., 2009. Global Leadership Study: A Theoretical Framework. Journal of Leadership Education. Vol 8, Issue $2-72$.

56. Perry, L. J., \& Thomason, M., 2010. Collaboration Processes: Inside the Black Box: A Literature-Bassed Assessment : Perry, L. J., ed. 2010.The JosseyBass Reader on Nonprofit \& Public Leadership. San Francisco: Josseybass. Ch. 10.

57. Pfister, A, J., 2009. Managing Organizational Culture for Effective Internal Control, from practice to theory. Zurich, Physica-Verlag.

58. Quinn, E. R., \& Rohrbaugh, J., 1983. A SPATIAL MODEL OF EFFECTIVENESS CRITERIA: TOWARDS A COMPETING VALUES APPROACH TO ORGANIZATIONAL EFFECTIVENESS. Management Science. Vol. 29, No, 3. U.S.A.

59. Reimann, C. B., 1975. Organizational Effectiveness and Managements Public Values: A Canonical Analysis. Vol. 18, No, 2. University of Pennsylvania

60. Robbins, S.P., \& Judge, T.A., 2011. Organizational Behavior. Fourth Edition. England: Pearson Education limited.

61. Robbins, S.P., \& Judge, T.A., 2013. Organizational Behavior. Fifteenth Edition. England: Pearson Education limited.

62. Rockall, A., \& Gertsch, F., 2001. Leadership Basics: A Guide to Leading Groups of Volunteers. Federation of Ontario Naturalists. Don Mills, Ontari.

63. Rollinson, D., Broadfield, A., \& Edward, J. D., 1998. Organizational Behaviour \& Analysis, An Integrated Approach. England: Addison-Wesley. 
64. Schein, H. E., 2004. Organizational Culture \& Leadership. Third Edition. USA. Jossey-Bass.

65. Schein, H. E., 2010. Organizational Culture \& Leadership. Fourth Edition. USA. Jossey-Bass.

66. Schein, H. E., 2010. The Learning Leader as Culture Manager: A Literature-Bassed Assessment In: Perry, L. J., ed. 2010.The Jossey-Bass Reader on Nonprofit and Public Leadership. San Francisco: Jossey-bass. Ch. 14.

67. Semerek, E, R., 2010. Cultural Perspectives of Academia: Towards a Model of Cultural Complexity. Higher Education: Handbook of Theory and Research. University of Michigan, Springer Science+Business Media.

68. Shore, M. L., \& Martin, J. H., 1989. Job statisfaction \& Oragnizational Commitment in Relation to Work Performance and Turnover Intentions. Human Relations, Vol 42, No 7, pp. 625-638

69. Sowa, E. J., Selden, C. S., \& Sandfort, R. J., 2004. No Longer Unmeasurable? AMultidimensional Integrated Model of Nonprofit Organizational Effectiveness. Nonprofit and Voluntary Sector Quarterly, vol. 33, no. 4.

70. Sparrow, P., \& West, M., 2002. Psychology and Organizational Effectiveness: A Literature-Based Assessment In: Robertson, T. I., Callinan, M., \& Bartram, D., ed. 2002. Organizational Effectiveness The Role of Psychology. UK: John Wiley \& Sons, Ltd. Ch. 1.

71. SPSS, Chapter 4: Regression Analysis, 2007 (15/12/2015)

72. Sun, S., 2008. Organizational Culture and Its Themes. International Journal of Business and Management.Vol. 3, No. 12, pp. 137-141.

73. Surji, M. K., 2014. The Positive Affect of Leadership on Employee Performance and Its Impact on Improving Workplace Environment in Addition to Organizational Culture. European Journal of Business and Management. org.Vol.6, No.25.

74. Surji. M. K., 2015. Understanding Patients' Perception and Experience in Improving Quality Healthcare with one of the Leading Public Hospitals in Erbil, Iraq. European Journal of Business \& Management. Vol.7, No.2, pp. 127-151.

75. Talbot, C., 2008. Measuring Public Value: A competing values approach, A paper for The Work Foundation. Herbert Simon Institute. Manchester Business School

76. Van Wart, M., 2010. Public-Sector Leadership Theory: An Assessment: A Literature-Bassed Assessment In: Perry, L. J., ed. 2010.The Jossey-Bass Reader on Nonprofit and Public Leadership. San Francisco: Jossey-bass. Ch. 6.

77. Yu, T., \& Wu, N., 2009. A Review of Study on the Competing Values Framework. International Journal of Business and Management. Vol. 4, No. 7 